\author{
Zbigniew Długosz, Szymon Biały \\ Uniwersytet Pedagogiczny \\ im. Komisji Edukacji Narodowej \\ w Krakowie
}

\title{
Studia w zakresie turystyki na tle szkolnictwa wyższego w kraju
}

Od pewnego czasu coraz głośniej wyrażana jest opinia, że w związku z rysującym się spadkiem liczebności roczników niżowych przełomu lat 80. i 90. ubiegłego stulecia, spadać będzie liczba chętnych na studia, co zresztą w skali globalnej uwidacznia się od 2005 r. i co już odczuło wiele uczelni. Zmniejszająca się liczba kandydatów na poszczególne kierunki studiów w wielu uczelniach wynika jednak nie tylko z faktu spadku liczebności poszczególnych roczników, ale przede wszystkim z tego, że w ostatnich dwóch dekadach przełomu wieków zwielokrotniła się liczba tego typu placówek niepublicznych (tab. 1), otwierając szerokie, ale odpłatne, możliwości studiowania. Sprawcą tego stanu rzeczy jest zwiększający się popyt na odpowiednie wykształcenie, które w powszechnym mniemaniu ma nobilitować głównie młodych ludzi w hierarchii społecznej. Dziś często nie chodzi już tylko o zaspokojenie własnych zainteresowań, ale - ze względów ambicjonalnych - o fakt ukończenia studiów.

Stąd na publicznych uczelniach ograniczony limit miejsc (zgodnie z wytycznymi komisji akredytacyjnej liczba studentów mierzona jest potencjałem kadry dydaktycznej) zmusił wielu chętnych do studiowania odpłatnego i szukania szansy na uczelniach niepaństwowych, szczególnie na zmieniających się w czasie tzw. modnych kierunkach, gdzie część kadry z placówek państwowych znajduje dodatkowe zatrudnienie.

W roku akademickim 2009/2010 we wszystkich uczelniach w kraju studiowało ponad 1,9 mln studentów. Uczelni prowadzących studia na różnych poziomach kształcenia (nie licząc kolegiów nauczycielskich i języków obcych, niemających statusu uczelni wyższych i nieposiadających uprawnień do nadawania tytułów zawodowych oraz będących w likwidacji) było wówczas 456, z czego 131 państwowych, a 325 niepublicznych. Dodatkowo funkcjonowało 218 punktów filialnych (oddziały, wydziały, instytuty, ośrodki lub inne tego typu placówki zamiejscowe, nie licząc poza granicą w Wilnie - Filii Uniwersytetu w Białymstoku oraz we Lwowie - Wydziału Zamiejscowego Wyższej Szkoły Informatyki i Zarządzania w Rzeszowie), w tym 125 państwowych i 93 prywatnych.

Na podstawie Ustawy z dnia 27 lipca 2005 r. Prawo o szkolnictwie wyższym, spośród 131 uczelni państwowych 41 posiadało status uniwersytetu, $\mathrm{z}$ tego 18 były to uczelnie humanistyczne (w tym kościelne: Katolicki Uniwersytet Lubelski, Uniwersytet Kardynała S. Wyszyńskiego), 23 funkcjonowały jako tzw. uniwersytety przymiotnikowe (cztery ekonomiczne, siedem rolniczych, jeden muzyczny, jeden sztuk pięknych, dwa pedagogiczne, osiem medycznych), 35 posiadało status akademii (trzy humanistyczne, jedna ekonomiczna, trzy techniczne, dwie medyczne, trzy wojskowe, jedna teatralna, siedem muzycznych, siedem sztuk pięknych, sześć wychowania fizycznego, dwie morskie), pozostałe zaś to politechniki, uczelnie resortowe (Obrony Narodowej, Spraw Wewnętrznych, Administracji Publicznej) i państwowe wyższe szkoły zawodowe. 
Tab. 1. Liczba uczelni i liczba studentów w Polsce

\begin{tabular}{|c|c|c|c|c|c|c|}
\hline \multirow{2}{*}{ Rok* } & \multicolumn{3}{|c|}{ Uczelnie } & \multicolumn{3}{c|}{ Studenci (w tys.) } \\
\cline { 2 - 7 } & razem & publiczne** & niepubliczne*** & razem & publiczne***|$^{* \text { niepubliczne*** }}$ \\
\hline 1990 & 112 & - & - & 404 & - & - \\
\hline 1991 & 117 & - & - & 428 & - & - \\
\hline 1992 & 124 & 106 & 18 & 512 & 496 & 16 \\
\hline 1993 & 140 & 104 & 36 & 613 & 584 & 29 \\
\hline 1994 & 160 & 104 & 56 & 678 & 628 & 50 \\
\hline 1996 & 179 & 99 & 80 & 894 & 795 & 89 \\
\hline 1997 & 213 & 99 & 114 & 1071 & 928 & 143 \\
\hline 1998 & 242 & 96 & 146 & 1318 & 1091 & 227 \\
\hline 1999 & 266 & 108 & 158 & 1323 & 1002 & 321 \\
\hline 2000 & 288 & 114 & 174 & 1432 & 1013 & 419 \\
\hline 2001 & 310 & 115 & 195 & 1585 & 1113 & 472 \\
\hline 2002 & 344 & 123 & 221 & 1718 & 1209 & 509 \\
\hline 2003 & 377 & 125 & 252 & 1800 & 1271 & 529 \\
\hline 2004 & 400 & 126 & 274 & 1858 & 1313 & 546 \\
\hline 2005 & 427 & 126 & 301 & 1926 & 1344 & 552 \\
\hline 2006 & 445 & 130 & 315 & 1954 & 1333 & 591 \\
\hline 2007 & 449 & 130 & 319 & 1941 & 1301 & 640 \\
\hline 2008 & 455 & 131 & 324 & 1937 & 1277 & 632 \\
\hline 2009 & 456 & 131 & 325 & 1928 & 1268 & 632 \\
\hline
\end{tabular}

*rok podjęcia studiów, **łącznie ze szkołami resortu obrony narodowej, spraw wewnętrznych i administracji, ${ }^{* \star *}$ wraz z uczelniami wyznaniowymi

Źródło: roczniki statystyczne GUS.

Uczelnie wyższe i ich filie ulokowane są w 190 miejscowościach, przy czym publiczne w 109 ośrodkach, natomiast niepubliczne - w 146. Po wnikliwej analizie okazało się, że tylko w 38 miejscowościach, gdzie funkcjonują uczelnie państwowe bądź ich filie, nie było uczelni prywatnych, natomiast w 74 miejscowościach, gdzie ulokowały się wyższe szkoły niepubliczne, nie było uczelni państwowych. W przestrzennym rozkładzie uczelni (tab. 2) można zaobserwować dużą dysproporcję zarówno ich liczby, jak i ośrodków w poszczególnych regionach kraju. Najwięcej państwowych uczelni i ich filii zlokalizowanych jest w województwie mazowieckim, o ponad połowę mniej w śląskim, dolnośląskim, wielkopolskim i małopolskim, natomiast najmniej w opolskim i lubuskim. 
Tab. 2. Rozmieszczenie uczelni w Polsce

\begin{tabular}{|c|c|c|c|c|c|c|c|c|c|}
\hline \multirow[b]{2}{*}{ Województwo } & \multicolumn{3}{|c|}{ Ogółem } & \multicolumn{3}{|c|}{ Uczelnie publiczne } & \multicolumn{3}{|c|}{ Uczelnie niepubliczne } \\
\hline & 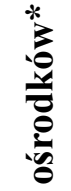 & שֶ & $: \equiv$ & 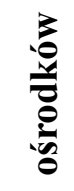 & 范 & $:$ & 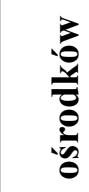 & 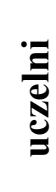 & $:=$ \\
\hline dolnośląskie & 14 & 41 & 20 & 9 & 13 & 12 & 9 & 28 & 8 \\
\hline $\begin{array}{l}\text { kujawsko- } \\
\text {-pomorskie }\end{array}$ & 7 & 20 & 23 & 5 & 5 & 7 & 7 & 15 & 6 \\
\hline lubelskie & 13 & 21 & 12 & 7 & 8 & 7 & 8 & 13 & 5 \\
\hline lubuskie & 6 & 8 & 8 & 5 & 3 & 8 & 4 & 5 & - \\
\hline łódzkie & 9 & 29 & 10 & 6 & 7 & 6 & 7 & 22 & 4 \\
\hline małopolskie & 11 & 35 & 14 & 8 & 14 & 10 & 9 & 21 & 4 \\
\hline mazowieckie & 25 & 108 & 23 & 7 & 19 & 10 & 23 & 89 & 13 \\
\hline opolskie & 3 & 6 & 2 & 2 & 4 & - & 2 & 2 & 2 \\
\hline podkarpackie & 18 & 17 & 14 & 10 & 7 & 6 & 12 & 10 & 8 \\
\hline podlaskie & 7 & 18 & 7 & 4 & 5 & 5 & 5 & 13 & 2 \\
\hline pomorskie & 9 & 29 & 11 & 5 & 9 & 4 & 10 & 20 & 7 \\
\hline śląskie & 22 & 44 & 31 & 17 & 11 & 23 & 15 & 33 & 8 \\
\hline świętokrzyskie & 8 & 15 & 6 & 3 & 3 & 2 & 7 & 12 & 4 \\
\hline $\begin{array}{l}\text { warmińsko- } \\
\text {-mazurskie }\end{array}$ & 10 & 10 & 7 & 3 & 3 & 2 & 8 & 7 & 5 \\
\hline wielkopolskie & 19 & 37 & 28 & 14 & 13 & 20 & 13 & 24 & 8 \\
\hline zachodnio-pomorskie & 9 & 20 & 12 & 4 & 7 & 3 & 7 & 13 & 9 \\
\hline
\end{tabular}

*ośrodki, w których ulokowane były uczelnie publiczne bądź niepubliczne i ich filie, liczono raz

Źródło: opracowanie własne na podstawie www.uczelnie.pl, www.nauka.gov.pl (dane na dzień 01.07.2010).

Od pewnego czasu jednym z popularnych i można rzec - modnych - kierunków studiów w Polsce jest turystyka, która zgodnie z rozporządzeniem MNiSW z dnia 13.06.2006 r. w myśl wyznaczonych standardów formalnie określana jest jako turystyka i rekreacja. Wśród najpopularniejszych kierunków turystyka w roku akademickim 2009/10 plasowała się na szóstym miejscu po: zarządzaniu, informatyce, finansach, pedagogice i administracji, a przed marketingiem. O popularności tej dyscypliny świadczy ogólnopolski ranking liczby kandydatów na jedno miejsce w poszczególnych uczelniach w ostatnich latach (tab. 3). Nie jest to może najlepszy wskaźnik, gdyż wynika on w dużej mierze nie tylko z pozycji uczelni na krajowym rynku edukacyjnym, ale przede wszystkim z liczby oferowanych przez uczelnię miejsc. Niemniej 
jednak, jak się wydaje, jest to jedyny i porównywalny dla wszystkich jednostek wskaźnik oddający popularność danego kierunku w Polsce. Ponadto należy pamiętać, że od pewnego czasu w niektórych uczelniach kandydaci mogą rejestrować się po opłaceniu wpisowego na dowolną liczbę kierunków bądź specjalności, co również zaburza stan faktyczny liczby chętnych na dany kierunek.

Tab. 3. Turystyka w rankingu popularności w polskich uczelniach

\begin{tabular}{|c|c|c|c|c|}
\hline $\begin{array}{c}\text { Rok } \\
\text { akademicki }\end{array}$ & Uczelnia - ośrodek & $\begin{array}{c}\text { Kandydat/ } \\
1 \text { miejsce }\end{array}$ & $\begin{array}{l}\text { Miejsce } \\
\text { w kraju }\end{array}$ & Kierunek/specjalizacja \\
\hline \multirow{3}{*}{$2003 / 4$} & SGGW - Warszawa & 28,9 & 1 & turystyka i rekreacja \\
\hline & AWF - Wrocław & 8,7 & 20 & turystyka i rekreacja \\
\hline & Politechnika Białostocka & 7,1 & 37 & turystyka i rekreacja \\
\hline \multirow{3}{*}{$2004 / 5$} & UJ - Kraków & 31,1 & 3 & $\begin{array}{c}\text { zarządzanie } \\
\text { i marketing/zarz. w tur. }\end{array}$ \\
\hline & SGGW - Warszawa & 20,8 & 5 & turystyka i rekreacja \\
\hline & UAM - Poznań & 18,7 & 9 & turystyka i rekreacja \\
\hline \multirow[b]{2}{*}{$2005 / 6$} & SGGW - Warszawa & 23,3 & 3 & turystyka i rekreacja \\
\hline & UJ - Kraków & 5,7 & 46 & $\begin{array}{c}\text { zarządzanie } \\
\text { i marketing/zarz. w tur. }\end{array}$ \\
\hline \multirow{3}{*}{$2006 / 7$} & SGGW - Warszawa & 23,3 & 4 & turystyka i rekreacja \\
\hline & UAM - Poznań & 16,0 & 11 & turystyka i rekreacja \\
\hline & Politechnika Białostocka & 5,9 & 107 & turystyka i rekreacja \\
\hline \multirow{4}{*}{$2007 / 8$} & SGGW - Warszawa & 16,2 & 8 & turystyka i rekreacja \\
\hline & UEK - Kraków & 12,9 & 17 & turystyka i rekreacja \\
\hline & UAM - Poznań & 11,8 & 30 & turystyka i rekreacja \\
\hline & UMK - Toruń & 11,4 & 32 & turystyka i rekreacja \\
\hline \multirow{3}{*}{$2008 / 9$} & SGGW - Warszawa & 14,0 & 4 & turystyka i rekreacja \\
\hline & UAM - Poznań & 9,6 & 15 & turystyka i rekreacja \\
\hline & UEK - Kraków & 9,1 & 25 & turystyka i rekreacja \\
\hline \multirow{4}{*}{$2009 / 10$} & SGGW - Warszawa & 14,1 & 9 & turystyka i rekreacja \\
\hline & UP - Kraków & 10,2 & & turystyka i rekreacja \\
\hline & UAM - Poznań & 8,6 & 52 & turystyka i rekreacja \\
\hline & UEK - Kraków & 7,1 & 81 & turystyka i rekreacja \\
\hline
\end{tabular}

Źródło: opracowanie własne na podstawie www.uczelnie.pl (dane na dzień 01.07.2010), źródła własne. 
Tab. 4. Turystyka na krajowym rynku edukacyjnych wśród wyższych szkół wg województw (stan na 01.06.2010 r.)

\begin{tabular}{|c|c|}
\hline Ośrodek & Uczelnia \\
\hline & dolnoślaskie \\
\hline \multirow{2}{*}{ Legnica } & Państwowa Wyższa Szkoła Zawodowa im. Witelona \\
\hline & Wyższa Szkoła Zarządzania/Polish Open University \\
\hline Świdnica & Wyższa Szkoła Technologii Teleinformatycznych \\
\hline Wałbrzych & Państwowa Wyższa Szkoła Zawodowa im. A. Silesiusa \\
\hline \multirow{9}{*}{ Wrocław } & Akademia Wychowania Fizycznego \\
\hline & Dolnoślaska Szkoła Wyższa Edukacji Towarzystwa Wiedzy Powszechnej \\
\hline & Szkoła Wyższa Rzemiost Artystycznych i Zarządzania \\
\hline & Uniwersytet Ekonomiczny \\
\hline & Wrocławska Wyższa Szkoła Informatyki Stosowanej „HORYZONT” \\
\hline & Wyższa Szkoła Bankowa \\
\hline & Wyższa Szkoła Edukacja w Sporcie \\
\hline & Wyższa Szkoła Handlowa \\
\hline & Wyższa Szkoła Zarządzania „Edukacja” \\
\hline \multicolumn{2}{|r|}{ kujawsko-pomorskie } \\
\hline Brodnica & $\begin{array}{l}\text { Wydziat Zamiejscowy Społecznej Wyższej Szkoty } \\
\text { Przedsiębiorczości i Zarządzania w Łodzi }\end{array}$ \\
\hline \multirow{5}{*}{ Bydgoszcz } & Kujawsko-Pomorska Szkoła Wyższa \\
\hline & Uniwersytet Kazimierza Wielkiego \\
\hline & Wyższa Szkoła Gospodarki \\
\hline & Zamiejscowy Ośrodek Dydaktyczny Uniwersytetu Ekonomicznego w Poznaniu \\
\hline & Zamiejscowy Wydział Wyższej Szkoty Bankowej w Toruniu \\
\hline \multirow{4}{*}{ Toruń } & Toruńska Wyższa Szkoła Przedsiębiorczości \\
\hline & Uniwersytet Mikołaja Kopernika \\
\hline & Wyższa Szkoła Bankowa \\
\hline & Wyższa Szkoła Kultury Społecznej i Medialnej \\
\hline \multirow[t]{2}{*}{ Włocławek } & Państwowa Wyższa Szkoła Zawodowa \\
\hline & Wyższa Szkoła Humanistyczno-Ekonomiczna \\
\hline \multicolumn{2}{|r|}{ lubelskie } \\
\hline \multirow[t]{2}{*}{ Biała Podlaska } & Państwowa Wyższa Szkoła Zawodowa im. Papieża Jana Pawła II \\
\hline & Zamiejscowy Wydział Wychowania Fizycznego AWF w Warszawie \\
\hline Chełm & Państwowa Wyższa Szkoła Zawodowa \\
\hline Kazimierz Dln. & Kolegium Sztuk Pięknych UMCS \\
\hline
\end{tabular}




\begin{tabular}{|c|c|}
\hline \multirow{4}{*}{ Lublin } & UMCS \\
\hline & Uniwersytet Przyrodniczy \\
\hline & Wyższa Szkoła Ekonomii i Innowacji \\
\hline & Wyższa Szkoła Społeczno-Przyrodnicza \\
\hline Ryki & Lubelska Szkoła Wyższa \\
\hline \multirow{2}{*}{ Zamość } & Państwowa Wyższa Szkoła Zawodowa im. S. Szymonowica \\
\hline & Wydział Nauk Rolniczych Uniwersytetu Przyrodniczego w Lublinie \\
\hline \multicolumn{2}{|r|}{ lubuskie } \\
\hline \multirow[t]{2}{*}{ Gorzów Wlkp. } & Państwowa Wyższa Szkoła Zawodowa \\
\hline & Zamiejscowy Wydział Kultury Fizycznej AWF w Poznaniu \\
\hline Sulechów & Państwowa Wyższa Szkoła Zawodowa \\
\hline Zielona Góra & Zamiejscowy Ośrodek Dydaktyczny Uniwersytetu Ekonomicznego w Poznaniu \\
\hline \multicolumn{2}{|r|}{ lódzkie } \\
\hline \multirow{6}{*}{ Łódź } & Akademia Humanistyczno-Ekonomiczna \\
\hline & Uniwersytet Łódzki \\
\hline & Wyższa Szkoła Edukacji Zdrowotnej i Nauk Społecznych \\
\hline & Wyższa Szkoła Pedagogiczna \\
\hline & Wyższa Szkoła Studiów Międzynarodowych \\
\hline & Wyższa Szkoła Turystyki i Hotelarstwa \\
\hline \multirow{2}{*}{$\begin{array}{l}\text { Piotrków } \\
\text { Trybunalski }\end{array}$} & $\begin{array}{c}\text { Punkt Informacyjno-Rekrutacyjny Wyższej Szkoły } \\
\text { Humanistyczno-Ekonomicznej w Lodzi }\end{array}$ \\
\hline & Wyższa Szkoła Handlowa im. króla S. Batorego \\
\hline \multicolumn{2}{|r|}{ małopolskie } \\
\hline Chrzanów & Wyższa Szkoła Przedsiębiorczości i Marketingu \\
\hline \multirow{10}{*}{ Kraków } & Akademia Górniczo-Hutnicza im. Stanisława Staszica \\
\hline & Akademia Wychowania Fizycznego im. B. Czecha \\
\hline & Krakowska Akademia im. F. Modrzewskiego \\
\hline & Małopolska Wyższa Szkoła Zawodowa im. Józefa Dietla \\
\hline & Uniwersytet Ekonomiczny \\
\hline & Uniwersytet Jagielloński \\
\hline & Uniwersytet Pedagogiczny im. KEN \\
\hline & Wyższa Szkoła Ekonomii i Informatyki \\
\hline & Wyższa Szkoła Ubezpieczeń \\
\hline & Wyższa Szkoła Zarządzania/The Polish Open University \\
\hline \multirow{2}{*}{ Nowy Sącz } & Państwowa Wyższa Szkoła Zawodowa \\
\hline & Wyższa Szkoła Przedsiębiorczości \\
\hline
\end{tabular}




\begin{tabular}{|c|c|}
\hline Nowy Targ & Podhalańska Państwowa Wyższa Szkoła Zawodowa \\
\hline Sucha Beskidzka & Wyższa Szkoła Turystyki i Ekologii \\
\hline \multirow{2}{*}{ Tarnów } & Małopolska Wyższa Szkoła Ekonomiczna \\
\hline & Wydziat Zamiejscowy W.S. Biznesu/National Louis University \\
\hline \multicolumn{2}{|r|}{ mazowieckie } \\
\hline Ciechanów & Wydziat Akademii Humanistycznej im. A. Gieysztora w Puttusku \\
\hline Gostynin & Wydziat Zamiejscowy W.S. Turystyki i Hotelarstwa w Lodzi \\
\hline Legionowo & Wyższa Szkoła Ekonomiczno-Techniczna im. W. Sikorskiego \\
\hline Płock & Państwowa Wyższa Szkoła Zawodowa \\
\hline Pruszków & Wyższa Szkoła Kultury Fizycznej i Turystyki im. H. Konopackiej \\
\hline Pultusk & Akademia Humanistyczna im. A. Gieysztora \\
\hline \multirow{5}{*}{ Radom } & Prywatna Wyższa Szkoła Ochrony Środowiska \\
\hline & Społeczna Wyższa Szkoła Przedsiębiorczości i Zarządzania \\
\hline & Wyższa Szkoła Biznesu im. bp. J. Chrapka \\
\hline & Wyższa Szkoła Handlowa \\
\hline & Wyższa Szkoła Nauk Społecznych i Technicznych \\
\hline Siedlce & Akademia Podlaska \\
\hline Sochaczew & Wyższa Szkoła Zarządzania i Marketingu \\
\hline \multirow{18}{*}{ Warszawa } & Akademia Wychowania Fizycznego im. J. Piłsudskiego \\
\hline & ALMAMER Wyższa Szkoła Ekonomiczna \\
\hline & OLYMPUS Szkoła Wyższa im. R. Kudlińskiego \\
\hline & Szkoła Główna Gospodarstwa Wiejskiego \\
\hline & Szkoła Główna Handlowa \\
\hline & Szkoła Wyższa Przymierza Rodzin \\
\hline & Uczelnia Warszawska im. M. Skłodowskiej-Curie \\
\hline & Wszechnica Polska - Szkoła Wyższa Towarzystwa Wiedzy Powszechnej \\
\hline & Wyższa Szkoła-Edukacja w Sporcie \\
\hline & Wyższa Szkoła Ekologii i Zarządzania \\
\hline & Wyższa Szkoła Ekonomiczno-Informatyczna \\
\hline & Wyższa Szkoła Finansów i Zarządzania \\
\hline & Wyższa Szkoła Handlu i Finansów Międzynarodowych im. F. Skarbka \\
\hline & Wyższa Szkoła Hotelarstwa, Gastronomii i Turystyki \\
\hline & Wyższa Szkoła Organizacji Turystyki i Hotelarstwa \\
\hline & Wyższa Szkoła Turystyki i Języków Obcych \\
\hline & Wyższa Szkoła Turystyki i Rekreacji im. M. Orłowicza \\
\hline & Szkoła Zarządzania i Prawa im. H. Chodkowskiej \\
\hline
\end{tabular}




\begin{tabular}{|c|c|}
\hline & opolskie \\
\hline \multirow[t]{2}{*}{ Opole } & Politechnika Opolska \\
\hline & Wydział Ekonomiczny Wyższej Szkoły Bankowej we Wrocławiu \\
\hline \multicolumn{2}{|r|}{ podkarpackie } \\
\hline Jarosław & Państwowa Wyższa Szkoła Zawodowa im. ks. B. Markiewicza* \\
\hline Jasło & Podkarpacka Szkoła Wyższa im Bt. Ks. W. Findysza \\
\hline Krosno & Państwowa Wyższa Szkoła Zawodowa \\
\hline Przemyśl & Państwowa Wyższa Szkoła Wschodnioeuropejska \\
\hline \multirow{3}{*}{ Rzeszów } & Uniwersytet Rzeszowski \\
\hline & Wyższa Szkoła Informatyki i Zarządzania \\
\hline & Wyższa Szkoła Inżynieryjno-Ekonomiczna \\
\hline Sanok & Państwowa Wyższa Szkoła Zawodowa im. J. Grodka \\
\hline Stalowa Wola & Wyższa Szkoła Ekonomiczna \\
\hline Tarnobrzeg & Państwowa Wyższa Szkoła Zawodowa im. S. Tarnowskiego \\
\hline \multicolumn{2}{|r|}{ podlaskie } \\
\hline \multirow{5}{*}{ Białystok } & Politechnika Białostocka \\
\hline & Wyższa Szkoła Ekonomiczna \\
\hline & Wyższa Szkoła Finansów i Zarządzania \\
\hline & Wyższa Szkoła Menedżerska \\
\hline & Wyższa Szkoła Wychowania Fizycznego i Turystyki \\
\hline Łomża & Wyższa Szkoła Agrobiznesu \\
\hline Siemiatycze & Nadbużańska Szkoła Wyższa \\
\hline \multirow{2}{*}{ Suwałki } & Państwowa Wyższa Szkoła Zawodowa \\
\hline & Wyższa Szkoła Suwalsko-Mazurska im. Jana Pawła II \\
\hline \multicolumn{2}{|r|}{ pomorskie } \\
\hline Człuchów & Wydział Zamiejscowy WSP Towarzystwa Wiedzy Powszechnej w Warszawie \\
\hline \multirow{6}{*}{ Gdańsk } & Akademia Wychowania Fizycznego i Sportu im. J. Śniadeckiego \\
\hline & Gdańska Wyższa Szkoła Humanistyczna \\
\hline & Uniwersytet Gdański \\
\hline & Wyższa Szkoła Bankowa \\
\hline & Wyższa Szkoła Turystyki i Hotelarstwa \\
\hline & Wyższa Szkoła Zarządzania \\
\hline \multirow{3}{*}{ Gdynia } & Pomorska Wyższa Szkoła Humanistyczna \\
\hline & Wydział Ekonomii i Zarządzania Wyższej Szkoły Bankowej w Gdańsku \\
\hline & Wyższa Szkoła Komunikacji Społecznej \\
\hline
\end{tabular}




\begin{tabular}{|c|c|}
\hline \multirow{2}{*}{ Słupsk } & Akademia Pomorska \\
\hline & Wyższa Hanzeatycka Szkoła Zarządzania \\
\hline Sopot & Europejska Szkoła Hotelarstwa, Turystyki i Przedsiębiorczości \\
\hline \multicolumn{2}{|r|}{ śląskie } \\
\hline \multirow{2}{*}{ Bielsko-Biała } & Wyższa Szkoła Bankowości i Finansów \\
\hline & Wyższa Szkoła Ekonomiczno-Humanistyczna \\
\hline \multirow{2}{*}{ Chorzów } & Górnośląska Wyższa Szkoła Przedsiębiorczości im. K. Goduli \\
\hline & Wydział Zamiejscowy Wyższej Szkoły Bankowej w Poznaniu \\
\hline Częstochowa & Wyższa Szkoła Hotelarstwa i Turystyki \\
\hline Dąbrowa Górnicza & Wyższa Szkoła Biznesu \\
\hline Gliwice & Gliwicka Wyższa Szkoła Przedsiębiorczości \\
\hline \multirow{5}{*}{ Katowice } & Akademia Ekonomiczna im. K. Adamieckiego \\
\hline & Akademia Wychowania Fizycznego im. J. Kukuczki \\
\hline & Górnośląska Wyższa Szkoła Handlowa im. W. Korfantego \\
\hline & Uniwersytet Śląski \\
\hline & Wyższa Szkoła Zarządzania Marketingowego i Języków Obcych \\
\hline Sosnowiec & Wyższa Szkoła Humanitas \\
\hline Ustroń & $\begin{array}{c}\text { Wyższa Szkoła Inżynierii Dentystycznej i Nauk Humanistycznych } \\
\text { im. prof. Meissnera }\end{array}$ \\
\hline Zawiercie & Wyższa Szkoła Administracji i Zarządzania \\
\hline Żywiec & Beskidzka Wyższa Szkoła Umiejętności \\
\hline \multicolumn{2}{|r|}{ świętokrzyskie } \\
\hline \multirow{4}{*}{ Kielce } & Uniwersytet Humanistyczno-Przyrodniczy im. J. Kochanowskiego \\
\hline & Wszechnica Świętokrzyska \\
\hline & Wyższa Szkoła Ekonomii i Prawa im. prof. E. Lipińskiego \\
\hline & Wyższa Szkoła Umiejętności \\
\hline \multicolumn{2}{|r|}{ warmińsko-mazurskie } \\
\hline Elbląg & Państwowa Wyższa Szkoła Zawodowa \\
\hline Ełk & Wydziat Wyższej Szkoła Finansów i Zarządzania w Białymstoku \\
\hline Olsztyn & Uniwersytet Warmińsko-Mazurski \\
\hline \multicolumn{2}{|r|}{ wielkopolskie } \\
\hline Gniezno & Gnieźnieńska Wyższa Szkoła Humanistyczno-Menedżerska „,Milenium” \\
\hline Kalisz & Państwowa Wyższa Szkoła Zawodowa im. Prezydenta S. Wojciechowskiego \\
\hline Konin & Państwowa Wyższa Szkoła Zawodowa \\
\hline Leszno & Państwowa Wyższa Szkoła Zawodowa im. J.A. Komeńskiego \\
\hline
\end{tabular}




\begin{tabular}{|c|c|}
\hline \multirow{3}{*}{ Piła } & Państwowa Wyższa Szkoła Zawodowa im. S. Staszica \\
\hline & Wyższa Szkoła Biznesu \\
\hline & Zamiejscowy Ośrodek Dydaktyczny Uniwersytetu Ekonomicznego w Poznaniu \\
\hline \multirow{12}{*}{ Poznań } & Akademia Wychowania Fizycznego im. E. Piaseckiego \\
\hline & Uniwersytet Ekonomiczny \\
\hline & Uniwersytet im. Adama Mickiewicza \\
\hline & Uniwersytet Przyrodniczy \\
\hline & Wielkopolska Wyższa Szkoła Turystyki i Zarządzania \\
\hline & Wydziat Zamiejscowy Szkoty Wyższej Psychologii Społecznej w Warszawie \\
\hline & Wyższa Szkoła Bezpieczeństwa \\
\hline & Wyższa Szkoła Edukacji Integracyjnej i Interkulturowej \\
\hline & Wyższa Szkoła Handlu i Ustug \\
\hline & Wyższa Szkoła Hotelarstwa i Gastronomii \\
\hline & Wyższa Szkoła Nauk Humanistycznych i Dziennikarstwa \\
\hline & Wyższa Szkoła Zawodowa „Kadry dla Europy” \\
\hline \multicolumn{2}{|r|}{ zachodniopomorskie } \\
\hline Koszalin & Wydział Zamiejscowy Społecznej W. S. Przedsiębiorczości i Zarządzania w Łodzi \\
\hline \multirow{8}{*}{ Szczecin } & Szczecińska Szkoła Wyższa Collegium Balticum \\
\hline & Uniwersytet Szczeciński \\
\hline & Wydziat Zamiejscowy Wyższej Szkoty Edukacji i Terapii w Poznaniu \\
\hline & Wyższa Szkoła Bankowa \\
\hline & Wyższa Szkoła Ekonomiczno-Turystyczna \\
\hline & Wyższa Szkoła Humanistyczna Towarzystwa Wiedzy Powszechnej \\
\hline & Wyższa Szkoła Integracji Europejskiej \\
\hline & Wyższa Szkoła Zawodowa „, OECONOMICUS” PTE \\
\hline
\end{tabular}

kursywą wpisano nazwy uczelni niepublicznych

* W grudniu 2010 r. uczelnia zmieniła nazwę na Państwowa Wyższa Szkoła Techniczno-Ekonomiczna im. Ks. Bronisława Markiewicza

Źródło: opracowanie własne na podstawie: http://www.uczelnie.pl (dane na dzień 01.07.2010).

W zakresie turystyki kształci się studentów w Polsce w 75 ośrodkach na 183 uczelniach, w tym 63 państwowych (tab. 4). Edukacja na kierunku „turystyka i rekreacja” odbywa się w 83 uczelniach zarówno państwowych, jak i niepublicznych (ryc. 1). Turystyka prowadzona jest także w ramach wydziałów o tej nazwie, bądź w podstawowych jednostkach o innym profilu. Do wydziałów, przy których najczęściej afiliowana jest turystyka, należą dziedziny związane z ekonomią, wychowaniem fizycznym, naukami o Ziemi (gdzie lokowana jest geografia), stosunkami międzynarodowymi, administracją i zarządzaniem czy marketingiem. Turystyka funkcjonuje także w ramach różnych kierunków studiów (tab. 5). 
Tab. 5. Zestawienie kierunków ze specjalizacjami z turystyki

\begin{tabular}{|c|c|}
\hline archeologia & ochrona środowiska \\
\hline bezpieczeństwo narodowe & pedagogika \\
\hline administracja & politologia \\
\hline etnologia & przedsiębiorczość i zarządzanie* \\
\hline ekonomia & rolnictwo \\
\hline ekonomia i zarządzanie* & socjologia \\
\hline geografia & towarouni międzynarodowe \\
\hline gospodarka przestrzenna & zarządzanie \\
\hline gospodarka turystyczna* & zarządzanie i marketing* \\
\hline finanse i rachunkowość & zarządzanie i inżynieria produkcji* \\
\hline filologia & \\
\hline kulturoznawstwo & \\
\hline
\end{tabular}

* w oficjalnym wykazie MNiSW (z 2006 r.) tak ujęte nazwy kierunków nie występują

Źródło: opracowanie własne na podstawie www.uczelnie.pl, www.nauka.pl (dane na dzień 01.07.2010).

Ryc. 1. Rozmieszczenie uczelni prowadzących studia na kierunku turystyka i rekreacja, w tym ośrodki zamiejscowe, bez uczelni w likwidacji (stan na 01.06.2010)

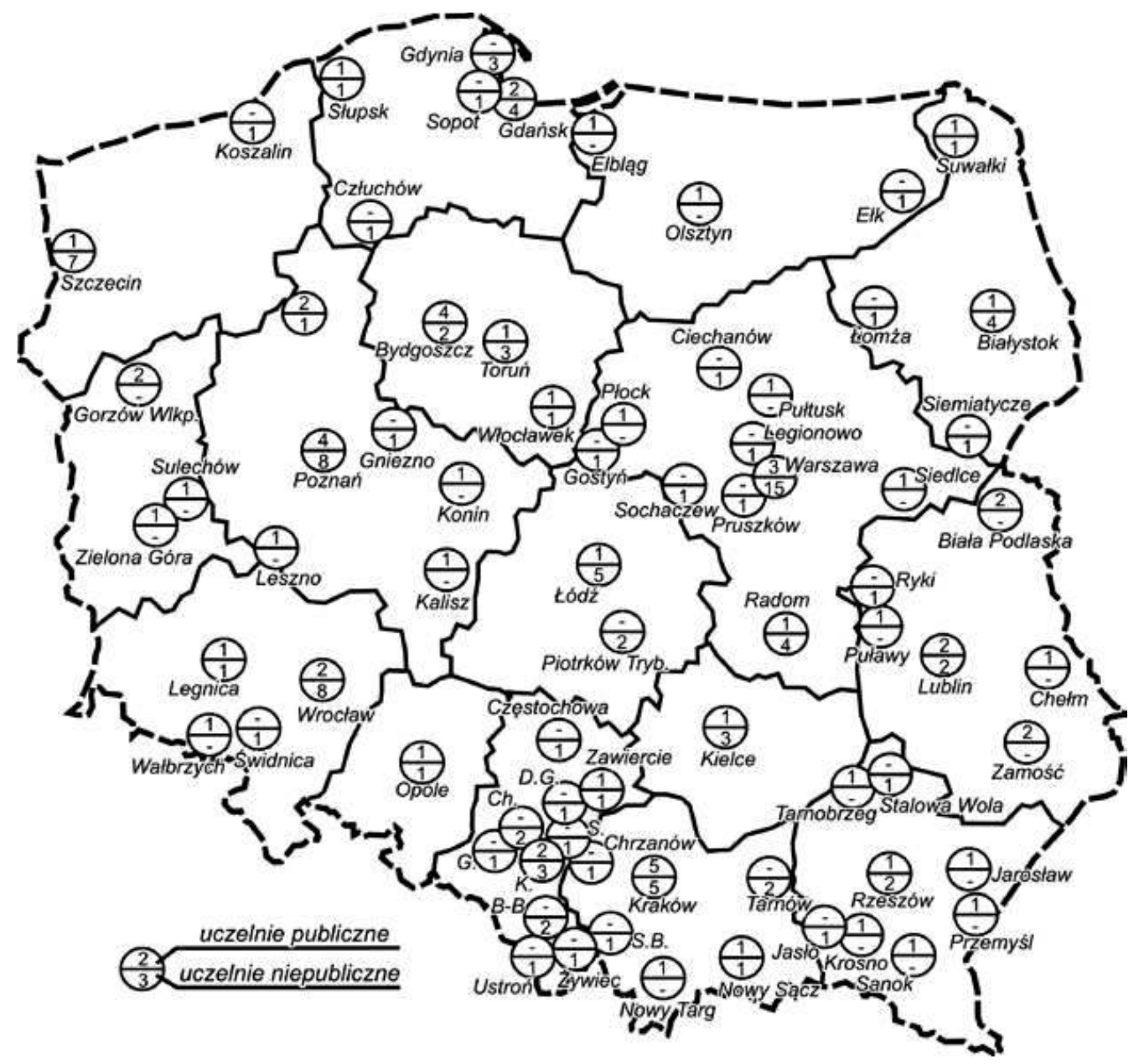

Źródło: opracowanie własne na podstawie www.uczelnie.pl, www.nauka.pl. 
Prawdziwą rewią bądź jak kto woli: koncertem życzeń z zakresu turystyki, są specjalizacje (123 - stan w roku akademickim 2009/10) prowadzone w ramach wydziałów lub kierunków. $\mathrm{Z}$ jednej strony są to pojedyncze albo rzadko spotykane u nas w kraju, bardzo ukierunkowane specjalizacje, takie jak animacja turystyki lotniczej, archeologia turystyczna, dietetyka w turystyce i rekreacji, język rosyjski (angielski) w turystyce, pedagogika sportu, rekreacji i turysty$\mathrm{ki}$, socjologia turystyki, wellness (medycyna alternatywna) i spa (leczenie wodą). Z drugiej strony, bardzo często oferowane są specjalności w różnorodnym, choć zbliżonym, ujęciu pojęciowym, jak m.in. agroturystyka, ekonomika turystyki, gospodarka turystyczna, organizacja bądź obsługa ruchu turystycznego, turystyka międzynarodowa, zarządzanie w turystyce czy krótko - turystyka.

Ryc. 2. Turystyka jako specjalność w uczelniach publicznych i ich filiach (stan na 30.06.2010)

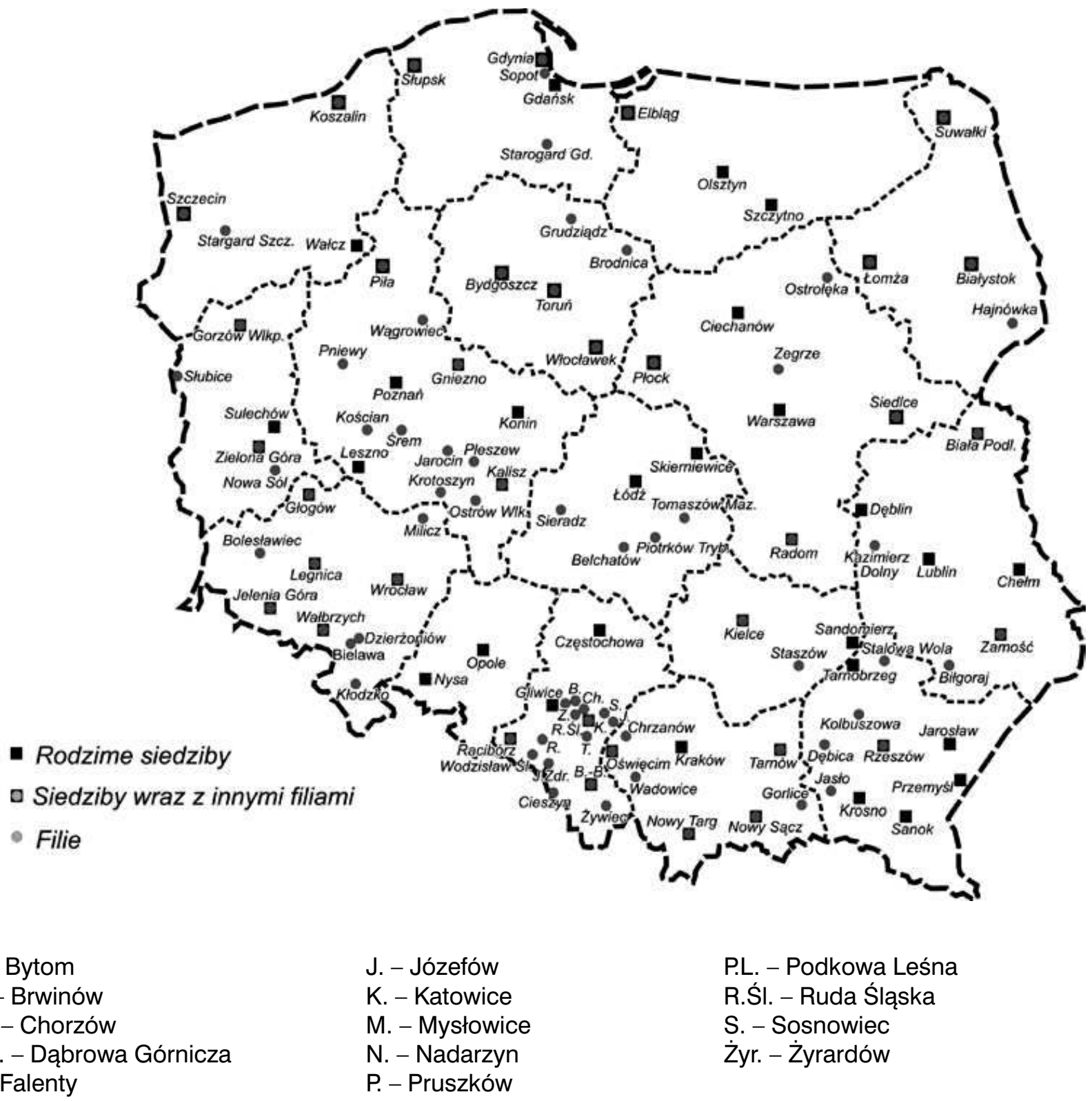

Źródło: opracowanie własne na podstawie www.uczelnie.pl, www.nauka.pl. 
Ryc. 3. Turystyka jako specjalność w uczelniach niepublicznych i ich filiach (stan na 30.06.2010 r.)

- Rodzime siedziby

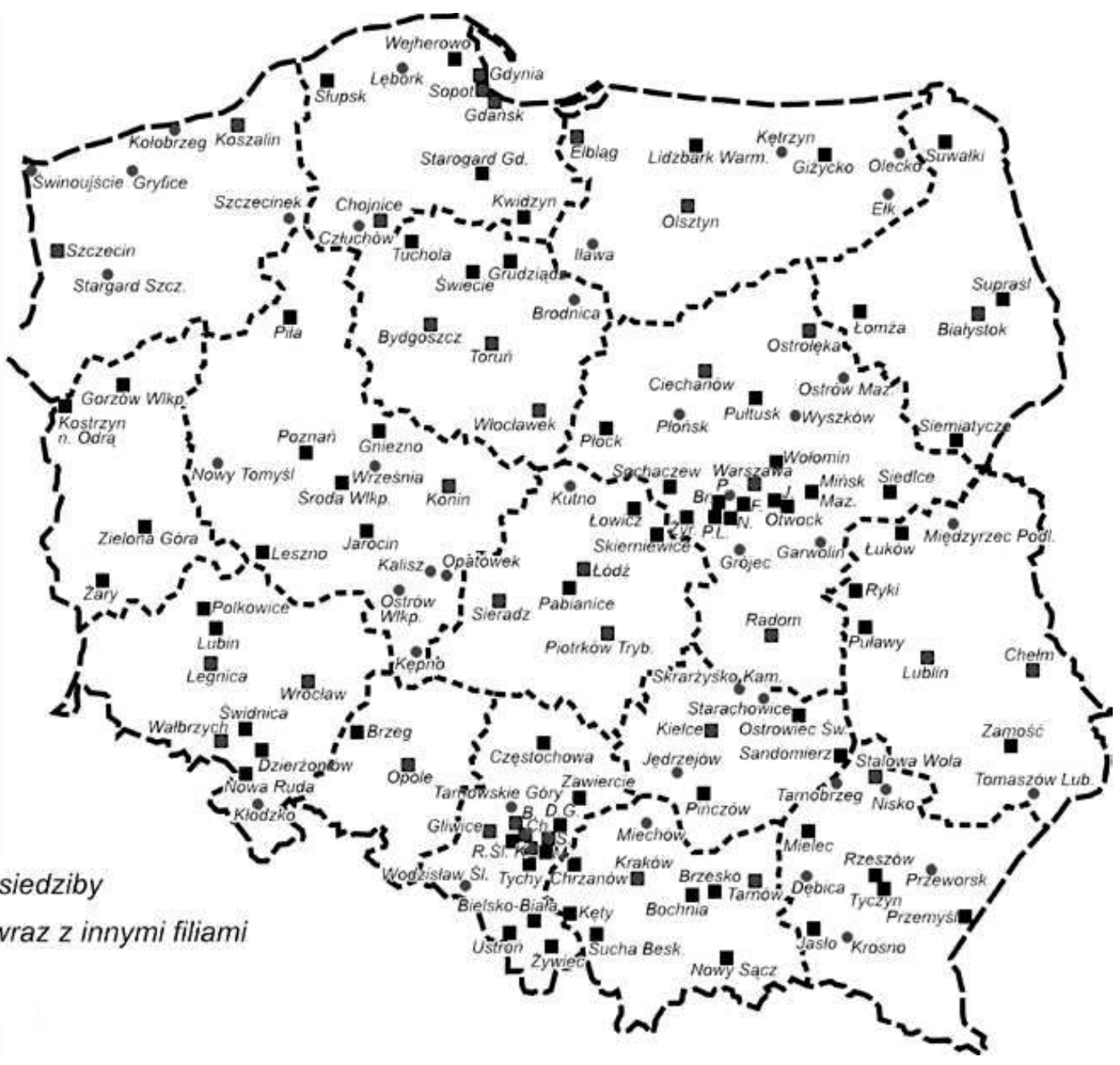

B. - Bytom

J. - Józefów

P.L. - Podkowa Leśna

Br. - Brwinów

K. - Katowice

R.Śl. - Ruda Śląska

Ch. - Chorzów

M. - Mysłowice

S. - Sosnowiec

D.G. - Dąbrowa Górnicza

N. - Nadarzyn

F. - Falenty

P. - Pruszków

Żyr. - Żyrardów

Źródło: opracowanie własne na podstawie www.uczelnie.pl, www.nauka.pl.

Analizując przestrzenne rozmieszczenie uczelni prowadzących studia w zakresie turystyki, tak w grupie uczelni państwowych (ryc. 2), jak i niepublicznych (ryc. 3), można stwierdzić, że największe możliwości studiowania turystyki lub dziedzin z nią związanych (rekreacji, hotelarstwa) reprezentowały uczelnie województw z dużymi ośrodkami, tj. mazowieckie (31 uczelni), wielkopolskie (19), małopolskie (17), śląskie (16). Zdecydowanie mniejsze możliwości studiowania turystyki oferowały uczelnie województw: opolskiego (dwie), warmińsko-mazurskiego (trzy) i lubuskiego (cztery). Ta popularność turystyki bierze się z kilku faktów, m.in. z:

- przejścia turystyki jako indywidualnej formy rekreacji w formę rekreacji masowej,

- rozwoju szeroko rozumianego sektora usług w tzw. obecnie przemysł turystyczny,

- nowych wyzwań w zakresie zrównoważonego rozwoju regionów turystycznych,

- pragmatycznych określeń wynikających z przystąpienia Polski do Unii Europejskiej i włączenia uznawania kwalifikacji związanych z zawodem (przewodnik turystyczny) lub działalnością (pilot wycieczek) w zakresie turystyki, 
- lansowanej do 2015 r. strategii w zakresie współpracy i promocji turystycznej Polski oraz kształtowania jej wizerunku jako kraju atrakcyjnego turystycznie.

Jednak rodzi się pytanie, czy i w jakim stopniu celowa jest dziś tak duża „produkcja” absolwentów turystyki. Czy celowym jest tworzenie nowych kierunków i specjalizacji? Na ile jest to celowe i racjonalne, zweryfikuje najbliższa przyszłość, m.in. poprzez poziom praktycznego przygotowania absolwentów do zawodu i znalezienia się ich na konkurencyjnym rynku w zakresie nie tylko wyuczonych specjalizacji.

\section{Studies in the Field of Tourism and Higher Education System in Poland}

In recent years, many universities have experienced decline in recruitment. This is due to decrease of birth rate of the late 80 's and 90 's and the increasing number of private higher education institutions, which allow payable studying. In the academic year 2009/10 1.9 million students in Poland were studying at 456 universities, including 131 public and 325 private ones. 41 state higher education institutions used name of university, of which 18 were humanities universities, and 23 so-called adjectival. 36 universities had the status of the academy. The others were polytechnics departmental universities and state schools of higher professional education.

Among the most popular fields of study Tourism and recreation took 6th place among the 125 in total, as indicated by the number of candidates for 1 place. Students are trained in the field of tourism in 75 municipalities in Poland at 183 universities, including 63 state ones. Tourism also occurs as 123 specializations in the various fields of study. It is found in the fields with similar educational profile, but also as rare and highly focused specializations. The most of universities educating in the field of Tourism and Recreation or related fields are in mazowieckie (31 universities), wielkopolskie (19), małopolskie (17) and śląskie (16) voivodeships. The smallest numbers of colleges offer such voivodeships as: opolskie (2), warmińsko-mazurskie (3) and lubuskie (4).

The popularity of this field is caused by the spread of mass tourism and rapid development of regions and sector of tourism services. An Important reason is also raising the professional qualifications and strategy for the promotion of Poland as a country attractive for tourists. However, the question arises, how useful it is to educate so many specialists in the field of tourism and whether the level of their education would allow them to find their place on a competitive labour market? 